\title{
The impact of brick (Agrochola circellaris Hufn.) and owlet moths (Lepidoptera: Noctuidae) on the health of seeds of field elms (Ulmus minor Mill.) in the landscape parks of the Świętokrzyskie Province
}

\author{
Wpływ zrzenicówki wiązowej (Agrochola circellaris Hufn.) \\ (Lepidoptera: Noctuidae) na zdrowotność nasion wiązu \\ polnego (Ulmus minor Mill.) w parkach krajobrazowych \\ województwa świętokrzyskiego
}

*Drhab. Jolanta Bąk-Badowska, Institute of Biology, The Jan Kochanowski University, Świętokrzyska 15 St., 25-406 Kielce, e-mail: jolanta.bak@ujk.edu.pl ${ }^{* *}$ Dr hab. Ilona Żeber-Dzikowska. Prof. Nadzw., Institute of Humanities and Social Sciences, The State School of Higher Professional Education in Płock, Gałczyńskiego 28 St., 09-400 Płock; Institute of Biology, The Jan Kochanowski University in Kielce, Świetokrzyska 15 St., 25-406 Kielce; e-mail: ilona.zeber-dzikowska@ujk.edu.pl
${ }^{* * *}$ Dr Jarosław Chmielewski, Institute of Environmental Protection-National Research, Krucza 5/11d St., 00-548 Warsaw, e-mail:j.chmielewski@ios.gov.pl

Keywords: Ulmus minor, seed pests, Agrochola circellaris, stand density, landscape parks, the Świętokrzyskie Province Słowa kluczowe: Ulmus minor, szkodniki nasion, Agrochola circellaris, zwarcie drzewostanu, parki krajobrazowe, województwo świętokrzyskie

\section{Abstract}

In the period of 2012-2013, a research was conducted to investigate the insects damaging the seeds of field elm (UImus minor Mill.). The aim of the research was to specify the damages to field elm seeds caused mainly by the brick (Agrochola circellaris) and to indicate the possible dependence between the number of damaged seeds by the caterpillars of this moth and stand density. The research was conducted in the areas of Cisów-Orłowiny Landscape Park (C-OLP) and Nida Landscape Park (NLP) in the Świętokrzyskie Province. In both parks, there were two test stands situated, each of which covered the material collected from the trees. The number of field elms ranged from four to six. Furthermore, a sample of 300 seeds were randomly collected from each tree. The elms in Cisów-Orłowiny Landscape Park were observed in full density stands (fully stocked stands); however, these trees in Nida Landscape Park were growing in loose density stands (under-stocked stands).

In total, there were 12,000 seeds collected from 20 trees. The analysis of the collected research material demonstrated that 436 seeds from the field elms (Ulmus minor) were damaged by the brick (Agrochola circellaris). It constituted $3.6 \%$ of the total number of collected samples (Table 1). In the seed samples collected from the test stands in Cisów-Orłowiny Landscape Park, the damages caused by the caterpillars of the brick moth ranged between $0.8 \%$ and $2.9 \%$. In the case of seed samples collected from Nida Landscape Park, the damages caused by the caterpillars of the brick moth were greater and ranged between $4.1 \%$ and $6.5 \%$. The percentage of undamaged seeds ranged between $94.4 \%$ in Cisów-Orłowiny Landscape Park and $84.7 \%$ in Nida Landscape Park, which constituted, on an average, $89.5 \%$ for both parks. The $6.8 \%$ of the seeds were also damaged by other insects.

\section{Streszczenie}

W latach 2012-2013 przeprowadzono badania dotyczące owadów uszkadzających nasiona wiązu polnego (Ulmus minor Mill.). Celem badań było określenie strat $w$ nasionach wiązu polnego powodowanych głównie przez zrzenicówkę wiązową (Agrochola circellaris) oraz wykazanie ewentualnej zależności między liczbą nasion uszkodzonych przez gąsienicę tego motyla a zwarciem drzewostanu. Badania prowadzono na obszarze Cisowsko-Orłowińskiego Parku Krajobrazowego (C-OPK) i Nadnidziańskiego Parku Krajobrazowego (NPK), położonych w województwie świętokrzyskim. W obu parkach wyznaczono po dwa stanowiska badawcze, na których wybrano od 4 do 6 drzew wiązu polnego. Z każdego drzewa zbierano losowo próby nasion w ilości po 300 sztuk. Wiązy na stanowiskach w C-OPK rosły w pełnym zwarciu, natomiast w NPK rosły w zwarciu luźnym.

Ogółem z 20 drzew pozyskano 12000 nasion. Analiza zebranego materiału wykazała, że 436 nasion wiązu polnego było uszkodzonych przez Agrochola circellaris. Stanowi to 3,6\% ogółu zebranego materiału (Tab.1). W próbach pobranych ze stanowisk w C-OPK zniszczenia wywołane przez gąsienicę motyla wahały się od $0,8 \%$ do $2,9 \%$. W przypadku prób pobranych w NPK szkody wyrządzone przez gąsienice tego motyla były większe i wynosiły od $4,1 \%$ do $6,5 \%$. Ilość nasion nieuszkodzonych wahała się od $94,4 \%$ w C-OPK, do $84,7 \%$ w NPK, co średnio dla obu parków wyniosło $89,5 \%$. Uszkodzenia nasion powodowały też inne owady, które zniszczyły $6,8 \%$ nasion.

W wyniku badań stwierdzono zależność między liczbą nasion wiązów uszkodzonych przez Agrochola circellaris a zwarciem drzewostanu (Tab. 2). Nasiona zebrane z drzew rosnących w NPK, w zwarciu luźnym, były 2-krotnie częściej uszkodzone niż te zebrane $z$ drzew rosnących w C-OPK, w zwarciu pełnym. 
The results of the research showed the dependence between the number of field elm seeds damaged by the brick Agrochola circellaris and the stand density (Table 2). The seeds collected from trees growing in the Nida Landscape Park in loose density stands (under-stocked stands) were twice as frequently damaged than those collected from the trees growing in Cisów-Orłowiny Landscape Park in full density stands. Also, the damages caused by other insects were greater among the seeds collected from trees growing in loose density stands than in full density stands (Table 1).

(C) IOŚ-PIB

\section{INTRODUCTION}

In 60 s and 70 s of the last century, a mass dieback of field elms (UImus sp.) took place. It was caused by, among others, the epidemics of the Dutch elm disease. This disease, which is widely spread in Europe, is caused by a member of the sac fungi (Ascomycota) from the family Ophiostoma. They can be spread by two species of bark beetles from the subfamily Scolytinae, namely, the large European elm bark beetles - Scolytus scolytus and the smaller European elm bark beetles - Scolytus multistriatus.

According to Głaz [1986], in the 1970s, the tree stands of different densities with the widespread field elms, constituted only $0.01 \%$ of the forest area in Poland. Furthermore, consistent with Napierała-Filipiak et al. [2014], the existing number of field elms in our forests was still insignificant and reached $0.24 \%$ of the entire area. The variety of elms (Ulmus sp.) involved 18 species, which inhabited the regions of Northern Hemisphere [Czekalski 1999]. In Poland, there are three naturally growing species of elms, namely the European white elm (also known as fluttering or spreading elm) - Ulmus laevis Pall., the wych elm (Scots elm) Ulmus glabra Huds. and the field elm - Ulmus minor Mill.

Due to their farming and utility properties and their high resistance to the industrial emission, they appear to be extremely valuable trees. The field elm (Ulmus minor), appearing in Poland mainly in the lowlands and foothills, is of particular economic value. The optimum conditions for its development are found in the riparian forests, wooded river valleys, among field bushes, and/or on soils with high mineral contents [Matuszkiewicz 2002]. Due to the insignificant contribution of the field elms in our forests and the relatively low germination capacity of their seeds, the nonnatural regeneration is necessary, that is, planning of trees. For this reason, the seeds of appropriate quality are needed. Among biotic factors, which are limiting the quantity and quality of seeds produced by field elms, an important role is played by the groups of multi-species insects [Schnaider 1991]. Their appearance and activities usually limit the number of seeds useful for nursery seedlings and natural regeneration.

The brick - Agrochola circellaris Hufn., the moth from the family Noctuidae, appears to be one of the insects most frequently damaging the elm seeds [Kurir 1978; Skrzypczyńska 2006].

The adult moths have a wingspan from $28 \mathrm{~mm}$ to $35 \mathrm{~mm}$. One can find eating caterpillars from early April to mid-May in the syncarps of elms. Such caterpillars can reach the length of up to $40 \mathrm{~mm}$ and just one caterpillar can destroy several dozens of elm
Również uszkodzenia spowodowane przez inne owady były większe wśród nasion z drzew rosnących w zwarciu luźnym, niż pełnym (Tab.1)

seeds. Apart from fruit and seeds, they seek food on leaves of willow (Salix sp.), oak (Quercus sp.), beech (Fagus sp.) and fruit trees. Due to the fact that the existing literature did not contain any information on the occurrence and harmfulness of the brick in the investigated areas, it appeared to be reasonable to conduct the research studies, which aimed at:

- $\quad$ indicating the damages to seeds of field elms (Ulmus minor) caused by the brick Agrochola circellaris,

indicating the possible dependence between the number of damaged seeds by caterpillars of the brick moth and stand densities.

\section{MATERIAL AND RESEARCH METHODS}

The field research was conducted in the third decade of May, in 2012 and 2013 in the areas of two parks located in the Świętokrzyskie Province, namely Cisów-Orłowiny Landscape Park (C-OLP) and Nida Landscape Park (NLP). These parks are situated in Małopolska Upland, specifically, in the macro-region of Kielce Upland and the Nida Basin [Kondracki 2002]. There were two test stands chosen in each park, and then four to six field elms (UImus minor) were chosen on each stand each. Next, samples of 300 seeds were collected from each tree in a random way. Primarily, the stand density was considered while selecting the test stands. In Cisów-Orłowiny Landscape Park, the chosen trees were a part of the elm and ash riparian forest - Ficario-Ulmetum minoris. The test stands, where the elm seeds were collected, were situated in Ujny (near the forest's lodge called Murawin) and near the village of Trzemosna. The elms there were found in the full density stands (i.e., fully stocked ones), with the tree crowns touching the edges of other crowns as well as partly overlapping them. To be precise, there were four trees selected in the area of Ujny and there were six trees chosen in Trzemosna.

In Nida Landscape Park, the alder and ash riparian forest Fraxino-Alnetum (where elms were also found) occurred in the slightly marshy habitat in the valley of watercourse. The elms selected for investigation from the area of Młodzawy and Umianowice (5 trees each) were growing in the loose density stands (under-stocked stands) with tree crowns slightly far away from other crowns and thinning.

Generally, the research involved the study of 12,000 seeds $(6,000$ from each park) (Table 1). The seeds were analysed considering 
Table 1. Results of health analyses of field elm (Ulmus minor Mill.) seeds collected from C-OLP and NLP in 2012 and 2013.

\begin{tabular}{|c|c|c|c|c|c|c|c|c|c|}
\hline \multirow{4}{*}{ Test stand } & \multicolumn{7}{|c|}{ Seed count } & & \\
\hline & \multirow{3}{*}{$\begin{array}{c}\text { sample } \\
\text { total }\end{array}$} & \multirow{2}{*}{\multicolumn{2}{|c|}{ undamaged/ intact }} & \multicolumn{4}{|c|}{ damaged by } & & \\
\hline & & & & \multicolumn{2}{|c|}{ Agrochola circellaris } & \multicolumn{2}{|c|}{ other insects } & \multicolumn{2}{|c|}{ Total } \\
\hline & & & $(\%)$ & & $(\%)$ & & (\%) & & (\%) \\
\hline \multicolumn{10}{|c|}{ Cisów-Orłowiny Landscape Park } \\
\hline \multicolumn{10}{|l|}{ Ujny } \\
\hline 2012 & 1,200 & 1,112 & 92.7 & 33 & 2.8 & 55 & 4.6 & 88 & 7.3 \\
\hline 2013 & 1,200 & 1,173 & 97.8 & 10 & 0.8 & 17 & 1.4 & 27 & 2.3 \\
\hline \multicolumn{10}{|l|}{ Trzemosna } \\
\hline 2012 & 1,800 & 1,659 & 92.2 & 52 & 2.9 & 89 & 4.9 & 141 & 7.8 \\
\hline 2013 & 1,800 & 1,721 & 95.6 & 24 & 1.3 & 55 & 3.1 & 79 & 4.4 \\
\hline Total & 6,000 & 5,665 & 94.4 & 119 & 2.0 & 216 & 3.5 & 335 & 5.45 \\
\hline \multicolumn{10}{|c|}{ Nida Landscape Park } \\
\hline \multicolumn{10}{|l|}{ Młodzawy } \\
\hline 2012 & 1,500 & 1,223 & 81.5 & 87 & 5.8 & 190 & 12.7 & 277 & 18.5 \\
\hline 2013 & 1,500 & 1,291 & 86.1 & 62 & 4.1 & 147 & 9.8 & 209 & 13.9 \\
\hline \multicolumn{10}{|l|}{ Umianowice } \\
\hline 2012 & 1,500 & 1,254 & 83.6 & 98 & 6.5 & 148 & 9.9 & 246 & 16.4 \\
\hline 2013 & 1,500 & 1,312 & 87.5 & 70 & 4.7 & 118 & 7.9 & 188 & 12.5 \\
\hline Total & 6,000 & 5,080 & 84.7 & 317 & 5.3 & 603 & 10.1 & 920 & 15.3 \\
\hline Grand total & 12,000 & 10,745 & 89.5 & 436 & 3.6 & 819 & 6.8 & 1255 & 10.5 \\
\hline
\end{tabular}

the damages caused mainly by the caterpillars of the brick moth (Agrochola circellaris). Their eating process was marked only by the unilateral consumption of seed coat (testa) and inner layers of the seed, while the seed wing was not damaged. As a result of such damage, a 'trough vallecula' appeared in the damaged seed [Stocki et al. 2007]. The caterpillars of the brick moth found eating were marked according to the research paper by Kapuściński [1966] and Kurira [1978]. A part of the analysed seeds had damages caused by other insects also and they should be the subject of another discussion.

Received data were used for statistical analyses. The statistical test, that is, the Shapiro-Wilk test was performed in order to find out if the data were compatible with a normal distribution, while the equality of variance for the groups was tested by performing Leaven's test [Sokal, Rohlf 2012]. Differences in the number of seeds damaged by the brick Agrochola circellaris in the tree stands growing in the fully stocked stands were tested by the $U$ Mann-Whitney test. It tested the null hypotheses that the population variances were equal. If the resulting $p$-value was less than some significance level, it was assumed to be $\alpha \leq 0.05$. The analysis was carried out using 'Statistica 10' package [StatSoft 2010].

\section{RESULTS AND DISCUSSION}

Analysis of the collected research material indicated that 436 seeds from the field elms (Ulmus minor) were damaged by the brick Agrochola circellaris. It constituted $3.6 \%$ of the total number of collected samples (Table 1).

In the samples collected from the two test stands in CisówOrłowiny Landscape Park, the damages caused by caterpillars (larvae) of the brick moth ranged between $0.8 \%$ (Ujny, in 2013) and $2.9 \%$ (Trzemosna, in 2012). For both test stands, considering both years, the brick Agrochola circellaris damaged a total of $2.0 \%$ elm seeds. Analysing the damages for each year separately, greater damages were acknowledged in both test stands in the first year, namely 2012 (Table 1). 
Table 2. The number of field elm seeds (UImus minor) damaged by the brick (Agrochola circellaris) in stands of different density in the landscape parks investigated.

\begin{tabular}{|c|c|c|c|c|}
\hline $\begin{array}{c}\text { Stand } \\
\text { density }\end{array}$ & $\begin{array}{c}\text { Means } \pm \text { standard } \\
\text { deviations }\end{array}$ & $\boldsymbol{n}$ & $\boldsymbol{Z}$ corr. & $\boldsymbol{P}$ \\
\hline full (C-OLP) & $1.98 \pm 1.07$ & 20 & & \\
\hline loose (NLP) & $5.28 \pm 3.01$ & 20 & & \\
\hline
\end{tabular}

C-OLP - Cisów-Orłowiny Landscape Park

NLP - Nida Landscape Park

$n-$ tree count

Z corr. $-Z$ corrected

In the case of samples collected in Nida Landscape Park, the damages caused mainly by the caterpillars (larvae) of the brick moth were greater and ranged between 4.1\% (Młodzawy, 2013) and 6.5\% (Umianowice, 2012). For both test stands, considering both years, the damages reached a total of $5.3 \%$. Also, in the first year of the research, it was shown that more seeds were damaged (respectively, $5.8 \%$ - Młodzawy and 6.5\% - Umianowice) than in 2013 (namely, 4.1\% - Młodzawy and 4.7\% - Umianowice) (Table 1).

The analysis of number of elm seeds indicated a significant influence of stand density on the number of damaged elm seeds by the brick Agrochola circellaris (Manna-Whitneya $U$ Test: $U=48, Z=-4.1085, P<0.001$ ) (Table 2).

In the collected samples, the damages of the elm seeds caused by other insects were also found. The analysis indicated 819 such seeds (in both parks together), which constituted $6.8 \%$ of the collected seed samples (Table 1).

As a consequence of the insignificant appearance of elms in our forests (including field elms), one should aim at increasing their number in the species composition of stands. Best quality of seeds is needed for this purpose. However, a considerable number of elm seeds seem to be damaged by insects. The brick Agrochola circellaris, the caterpillar from the family Noctuidae is among the insects damaging the elms. The knowledge regarding the harmfulness of this caterpillar are contradictory. According to Kristek [1992], this pest does not have any economic significance, whereas Kapuściński [1966] and Stocki et al. [2007] accept as true that the caterpillar of the moth could destroy up to $100 \%$ of the seeds on trees both in Poland and in the neighbouring countries.

The results of the research studies conducted by Skrzypczyńska [2006] in the area of Ojców National Park and in the area of the managed forest stand in the Forestry Management of Olkusz, indicated that the brick Agrochola circellaris played an insignificant role in the damages of the wych elm seeds (UImus glabra). It appeared that the choice of area (the protected area and the managed forest stand) did not influence the number of damages caused by the brick Agrochola circellaris to the wych elm seeds. The results showed the same percentage for both areas - reaching less than $1 \%$.
In this research, the selection of stands was based on the density of stands found in the research areas. The elms in CisowOrlowiny Landscape Park were located in the full density stands (fully stocked stands); however, in Nida Landscape Park, they were growing in the loose density stands (under-stocked stands) with the sun shining through the crowns of trees.

According to Tyszkiewicz [1952], the selected tree characteristics, such as the exposure and the stand density, have a considerable impact on the plentifulness of seeds, and thus, they influence the occurrence of insects in the seeds and their damages significantly. The studies considering entomofauna of cones and seeds of other trees, such as Larch (Larix sp.), European silver fir (Abies alba) and Norway Spruce (Picea abies), as well as the dependences between insects there and the selected characteristics of the stand were conducted by Skrzypczyńska [2012] and Bąk [2006]. In their work, the authors demonstrated that the seeds of trees growing in full density stands (fully stocked stands) were less frequently colonized and damaged by insects than the seeds of trees growing at the edge of the stand growing in loose density stands (under-stocked stands).

In the recent research, it was confirmed that the existence of elm seeds damaged by the brick Agrochola circellaris growing in the loose density stands (under-stocked stands) located in Nida Landscape Park was greater than in the full density stands (fully stocked stands) located in Cisów-Orłowiny Landscape Park. It reached appropriately $5.3 \%$ and $2.0 \%$. Such damages of elm seeds caused by other insects were almost three times greater in Nida Landscape Park growing in loose density stands (understocked stands) than in Cisów-Orłowiny Landscape Park (fully stocked stands).

\section{CONCLUSIONS}

The insignificant role in worsening the quality of the field elm seeds is played by the brick - Agrochola circellaris.

The dependence between the number of elm seeds damaged by the brick and the stand density was confirmed. The seeds collected from the trees growing in the loose stands (understocked stands) were twice frequently damaged than those collected from the trees growing in the full density stands (fully stocked stands).

Due to the process of elm weakening, the brick Agrochola circellaris can be a dangerous pest and can cause great loss in the number of seeds from these trees. 


\section{REFERENCES}

BĄK J. 2006. The occurrence of Megastigmus pictus (Förster) (Hymenoptera: Torymidae) and Resseliella skuhravyorum Skrzypcz. (Diptera: Cecidomyiidae) in the Chełmowa Góra forest reserve of the Świętokrzyski National Park (Poland). Journal of Forest Science 52, 6: 249-253.

CZEKALSKI M. 1999. Drzewo roku 1999 - wiąz; część I. Szkółkarstwo 1: 31-33.

GŁAZ J. 1986. Wiąz w Lasach Państwowych. Sylwan 130, 1: 2333.

KAPUŚCIŃSKI S. 1966. Szkodniki owadzie nasion drzew leśnych. PWRiL, Warszawa.

KONDRACKI J. 2002. Geografia regionalna Polski. PWN, Warszawa.

KRISTEK J. 1992. Škudci semen, šišek a plodu lesních dřevin. Brázda, Praha.

KURIR A. 1978. Noctuidae, Eulen. W: Schwenke W. (red.). Die Forstschädlinge Europas. Bd 3. Schmetterlinge. Verlag Paul Parey, Hamburg und Berlin: 266-305.

MATUSZKIEWICZ J. M. 2002. Zespoły leśne Polski. PWN, Warszawa

NAPIERAŁA-FILIPIAK A., FILIPIAK M., JAWOREK J. 2014. Rozmieszczenie zasobów drzew z rodzaju wiąz (UImus spp.) w lasach Polski w świetle dokumentacji leśnej. Sylwan 158, 11: 811-820.
SCHNAIDER Z. 1991. Atlas uszkodzeń drzew i krzewów powodowanych przez owady i pajęczaki. PWN, Warszawa.

SKRZYPCZYŃSKA M. 2006. Wpływ zrzenicówki wiązowej Agrochola circellaris [Hufnagel 1766] (Lepidoptera: Noctuidae) na zdrowotność nasion wiązu górskiego Ulmus glabra Huds. Sylwan 7: 35-37.

SKRZYPCZYŃSKA M. 2012. Uszkodzenia krótkopędów modrzewia europejskiego Larix decidua Mill. przez owady na wybranych stanowiskach w południowej Polsce. Sylwan 156, 11: 812-818.

SOKAL R.R., ROHLF F. J. 2012. Biometry: the principles and practice of statistics in biological research. Freeman W. H. and Co., New York.

STATSOFT INC. 2010. Statistica for windows. Stat Soft Inc Tulsa, Oklahoma.

STOCKI J., KINELSKI S., DZWONKOWSKI R. 2007. Szkodniki nasion i owoców drzew i krzewów leśnych. Multico, Warszawa.

TYSZKIEWICZ S. 1952. Nasiennictwo leśne z zarysem selekcji drzew. PWRiL, Warszawa. 